\title{
Water-melon Flesh and Broccoli Sprouts as Used to Cope the Oxidation Induced by Potassium Bromate.
}

\author{
${ }^{1}$ El-Sayed H. Bakr, ${ }^{2}$ Mona A. El-Yamany \\ ${ }^{1}$ Department of Nutrition and Food Sciences, Faculty of Home Economics, \\ Menoufia University, Shebin El Kom, Egypt. \\ ${ }^{2}$ Department of Family Education, Faculty of Education, Unvirsity of Umm \\ Al-Qura, Makka Al-Mukarama, KSA.
}

\section{Introduction:}

Oxidative stress is a phenomenon caused by an imbalance between production and accumulation of oxygen reactive species (ROS) in cells and tissues and the ability of a biological system to detoxify these reactive products. ROS can play, and in fact they do it, several physiological roles (i.e., cell signaling), and they are normally generated as by-products of oxygen metabolism; despite this, environmental stressors (i.e., UV, ionizing radiations, pollutants, and heavy metals) and xenobiotics (i.e., antiblastic drugs) contribute to greatly increase ROS production, therefore causing the imbalance that leads to cell and tissue damage (oxidative stress) (Pizzino et al., 2017).

Potassium bromate $\left(\mathrm{KBrO}_{3}\right)$ is an oxidizing agent that has been used as a food additive, mainly in the bread-making process. $\mathrm{KBrO}_{3}$ increased production of reactive oxygen species and free radicals (Ahmad and Mahmoud, 2012). International Agency for Research on Cancer (IARC) has classified $\mathrm{KBrO} 3$ as a possible human carcinogen (group 2B) and its application in food processing was restricted. Indeed, many previous reports has documented that $\mathrm{KBrO} 3$ can induce multiple organ toxicity in humans and experimental animals (Naif et al., 2018). Supporting the involvement of ROS in its action, several antioxidants (AO) have been shown to ameliorate the bromate-induced multiple organ toxicity (Khan et al., 2013).

Water-melon (Citrullus lanatus) is a pleasant-tasting fruit and one of the most economically important fruit in the Curcurbitaceae family. The fruit has both nutritional and medicinal values (Gwana et al., 2014). Watermelon fruit is composed of flesh (68\%), seeds (2\%) and rind approximately $30 \%$ of the total mass of the fruit (Romdhane et al., 2017). Water-melon fruit is considered as a rich source of vitamins $\mathrm{A}, \mathrm{B}, \mathrm{C}$ and $\mathrm{E}$ and minerals $\mathrm{K}, \mathrm{mg}, \mathrm{Ca}$ and $\mathrm{Fe}$ and antioxidants e.g., phenolics and carotenoids (Perkins-Veazie et al., 2007). The plant contains a significant amount of citrulline for improvement of erectile dysfunction. It possesses high level of antioxidant which decreases the 
risk of kidney stone and bone loss due to old age. It is a powerful diuretic diet with sufficient amino acid, beta-carotene which prevents ailment such as heart diseases. The lycopene content which gives the fruit its colour plays a role in the protection of prostrate and oral cancer (Gwana et al., 2014). Watermelon contains phytochemicals such as lycopene, vitamin $\mathrm{C}, \beta$-carotene, and Total polyphenolic content that possess anti-inflammatory, anticancer, and antioxidant properties. Dietary intake of these products with antioxidants properties is important in maintaining human health and well-being. These reduces incidence of chronic diseases such as hypertension, diabetes, cancer, and some coronary heart diseases, through inhibiting formation of free radicals and reactive oxygen species. The presence of these phytochemicals enhances its potential use as a functional ingredient in food application (Makaepea et al., 2019).

Broccoli, Brassica oleracea, variety Italica, belongs to the family Brassicaceae (Ravikumar, 2015). Broccoli sprouts also provides many healthpromoting properties which attributes to its antioxidant and anti-carcinogenic compounds. It's primely composed of polyphenols, glucosinolates, sulforaphane and selenium (Mahn and Reyes, 2012). They are also known to contain a high content of flavonoids, vitamins and mineral nutrients. Vitamin C, insoluble complexes, is a good adjuvant in iron therapy but can interfere with the metabolism of some drugs and antineoplastic agents. The presence of these contents has shown that broccoli provides immense benefits in protecting humans against cancer, and also assures to reduce the risk of specific cancers. One of the phytotherapeutic roles of broccoli is for skin diseases in which the juice of the leaves is used to treat warts (Moreno et al., 2006). The content of glucosinolates in Brassica plants is known to represent a healthy advantage as they are associated to antioxidant and anti-carcinogenic properties. Broccoli, being one of the varieties of Brassica sprouts, is grown to evaluate the glucosinolate profile and myrosinase activity during the sprouting. Glucoraphin is another major compound in broccoli sprouts (Vale et al., 2015). Sulforaphane is used as an antioxidant dietary supplement. It induces phase I and phase II enzymes to prevent carcinogenesis and also presents anti-tumor action at postinitiation phase suggesting supplementary roles in cancer prevention (M de Figueiredo et al., 2015). Meanwhile, Broccoli sprouts are an excellent source of health-promoting phytochemicals such as vitamins, glucosinolates, and phenolics (Thanh et al., 2019). Therefore, the present study was designed to investigate potential protective and ameliorate effect of red water-melon flesh and broccoli sprouts powders against $\mathrm{KBrO} 3$ induced oxidative stress 
Material and Methods:

Materials:

Plants:

The tested plant in this investigation were water-melon flesh (red meat) and broccoli sprouts, these plants were purchased from local market in Menoufia, Egypt.

Chemicals:

Potassium bromate $\left(\mathrm{KBrO}_{3}\right)$ in the form of a white powder was purchased from El-Gomhoria Company for Drugs and Medical Equipments, Cairo, Egypt.

Animals:

Thirty-six (36) adult male Sprague Dawley rats, average body weight $(150 \pm 10 \mathrm{~g})$ were used in this study. Rats were obtained from Research Institute of Ophthalmology, Medical Analysis Department, Giza, Egypt.

Basal diet composition of tested rats:

Diet consists of casein, sucrose, corn oil, choline chloride, vitamins mixture, mineral mixture, cellulose, and corn starch were purchased from ElGomhoria Company for Drugs and Medical Equipments, Cairo, Egypt.

\section{Methods:}

Experimental design:

Thirty-six (36) adult male albino rats were fed on basal diet for 7 days for acclimatization. Then, rats were randomly distributed into 6 equal groups, 6 rats each. Group 1(healthy rats) was fed on the basal diet and set as a negative control group (normal rats). The other 5 groups were injected by a single intraperitoneal dose of potassium bromate at dose of $125 \mathrm{mg} / \mathrm{kg}$ body weight for induction of oxidative stress according to the described method by Khan and Sultana (2004). All groups were fed for 4 weeks according to the following groups:

Group (1): (Control " - ") rats (n=6) were fed on basal diet only.

Group (2): (Control " + ") rats $(\mathrm{n}=6)$ were kept without any treatment and fed on basal diet after single intraperitoneal injection with $\mathrm{KBrO}_{3}(125$ $\mathrm{mg} / \mathrm{kg} \mathrm{B}$.Wt).

Group (3): rats $(n=6)$ were fed on basal diet containing 5\% water-melon flesh after single intraperitoneal injection with $\mathrm{KBrO}_{3}(125 \mathrm{mg} / \mathrm{kg} \mathrm{B} . \mathrm{Wt})$.

Group (4): rats $(n=6)$ were fed on basal diet containing $10 \%$ water-melon flesh after single intraperitoneal injection with $\mathrm{KBrO}_{3}(125 \mathrm{mg} / \mathrm{kg} \mathrm{B} . \mathrm{Wt})$.

Group (5): rats $(n=6)$ were fed on basal diet containing 5\% broccoli sprouts after single intraperitoneal injection with $\mathrm{KBrO}_{3}(125 \mathrm{mg} / \mathrm{kg} \mathrm{B} . \mathrm{Wt})$.

Group (6): rats $(n=6)$ were fed on basal diet containing $10 \%$ broccoli sprouts after single intraperitoneal injection with $\mathrm{KBrO}_{3}(125 \mathrm{mg} / \mathrm{kg} \mathrm{B} . \mathrm{Wt})$. 


\section{Determination of Biochemical Blood Parameters: \\ Blood Sampling:}

At the end of the experiment, rats were fasted overnight and anesthetized with diethyl ether. Blood samples were collected in clean dry centrifuge tubes from hepatic portal vein; serum obtained by centrifugation was carefully aspirated, transferred into clean cuvette tubes and stored frozen at $20^{\circ} \mathrm{C}$ for analysis (Malhotra, 2003).

Serum samples were analyzed for determination the following Parameters: Urea was determined according to the enzymatic method of Patton and Crouch (1977), creatinine was determined according to kinetic method of Henry (1974) and uric acid was determination according to the enzymatic colorimetric test of Fossati and Prencipe (1980). Aspartate amino transaminase (AST) and alanine amino transferase (ALT) activities were carried out according to the method of Yound (1975) and Tietz (1976). Alkaline phsphatase (ALP) activity was determined according to Belfield and Goldberg (1971). Total cholesterol (TC) was determined according to Allen, (1974), and high density lipoprotein cholesterol (HDL-c) according to Lopez (1997). The calculation of low density lipoprotein cholesterol (LDL-c) was carried out according to the method of Lee and Nieman (1996), atherogenic index (AI) was calculated according to Kikuchi et al., (1998) and triglycerides determined according to Fossati and Prencipe (1982). Serum glucose determined according to Kalpan (1984). Serum total protein (TP) determined according to the test of Gomal et al (1949), serum albumin was carried out as the method of Doumas et al (1971) and globulin was calculated as Charry and Sharma (2004). Bilirubin was determined according to Doumas et al., (1985), direct bilirubin and indirect bilirubin were measured according to Sepulveda and Osterberg (1943).

Statistical Analysis:

The data were statistically analyzed using a computerized Costate Program by one way ANOVA using a Completely Randomized Factorial Design (SAS, 1988) when a significant mean effect was detected, the means were separated with the Duncan's Multiple Range Test. Differences between treatments at $\mathrm{P} \leq 0.05$ were considered significant. The results are presented as mean \pm SD.

\section{Results and Discussion:}

Data presented in table (1) indicate the effect of water-melon flesh and broccoli sprouts on total cholesterol and triglycerides of $\mathrm{KBrO} 3$-intoxicated rats. It could be noticed that the mean value \pm SD of total cholesterol (TC) of control (+) group was higher than control (-) group, being 205 \pm 4.91 and $121 \pm 2.98 \mathrm{mg} / \mathrm{dl}$ respectively. The best serum (TC) level showed for the group 
fed on diet containing $10 \%$ water-melon flesh, and the group fed on diet containing $10 \%$ broccoli.

It could be observed that the mean value of triglycerides TG of control $(+)$ group was higher than control (-) group, being $177 \pm 5.03$ and $125 \pm 3.01$ $\mathrm{mg} / \mathrm{dl}$ respectively. The best serum (TG) level showed for group of (rats fed on diet containing $10 \%$ water-melon flesh), because this group showed significant decrease in TG, as compared to other treated groups.

Lee et al., (2009) reported that ethanol extract of broccoli sprouts (BS) in rats fed high fat diet reduces serum total cholesterol and triglycerides.

Abu-Hiamed (2018) showed that incorporation of 10\% water-melon into the diet of the otherwise hypercholesterolemic rats led to significant reduction in serum levels of total cholesterol.

Table (1): Effect of two levels from water-melon flesh and broccoli sprouts in diet on total cholesterol and tri-glycerides of $\mathrm{KBrO3}$ intoxicated rats

\begin{tabular}{|l||c|c|}
\hline \hline Groups & $\begin{array}{c}\text { TC }(\mathbf{m g} / \mathbf{d l}) \\
\text { Mean } \pm \text { SD }\end{array}$ & $\begin{array}{c}\text { TG }(\mathbf{m g} / \mathbf{d l}) \\
\text { Mean } \pm \text { SD }\end{array}$ \\
\hline \hline G1 (Control -ve) & $121.00^{\mathbf{b}} \pm 2.98$ & $125.00^{\mathbf{b}} \pm 3.01$ \\
\hline \hline G2 (Control +ve) & $205.00^{\mathbf{a}} \pm 4.91$ & $177.00^{\mathbf{a}} \pm 5.03$ \\
\hline \hline G3 (Water-melon flesh 5\%) & $100.00^{\mathbf{d}} \pm 1.39$ & $115.00^{\mathbf{d}} \pm 2.43$ \\
\hline \hline G4 (Water-melon flesh 10\%) & $98.00^{\mathbf{e}} \pm 2.90$ & $110.00^{\mathbf{e}} \pm 2.29$ \\
\hline \hline G5 (Broccoli sprouts $5 \%)$ & $111.00^{\mathbf{c}} \pm 2.29$ & $119.00^{\mathbf{c}} \pm 3.48$ \\
\hline \hline G6 (Broccoli sprouts 10\%) & $100.00^{\mathbf{d}} \pm 1.67$ & $115.00^{\mathbf{d}} \pm 1.98$ \\
\hline
\end{tabular}

- Least significant differences at $\mathrm{p} \leq 0.05$.

- Means with the same letter in each column are insignificantly difference.

Data presented in table (2) revealed the effect of water-melon flesh and broccoli sprouts on HDLc, LDLc, VLDLc \& AI of KBrO3-intoxicated rats.

It could be observed that the mean value of (HDLc) of control $(+)$ group was lower than control (-) group, being $36 \pm 2.81$ and $40 \pm 1.91 \mathrm{mg} / \mathrm{dl}$ respectively. The best level of serum HDLc showed for group of (rats fed on diet containing $10 \%$ water-melon flesh), followed by the group which treated with $10 \%$ broccoli, respectively.

It could be showed that the mean value of (LDLc) of control (-) group was lower than control (+) group, being $56 \pm 0.98$ and $134 \pm 3.01 \mathrm{mg} / \mathrm{dl}$ respectively. The best level of serum LDLc showed for group of (rats fed on diet containing $10 \%$ water-melon flesh), when compared to control $(+)$ and other treated groups.

The same table indicated that the mean value of (VLDLc) of control $(+)$ group was higher than control (-) group, being $35 \pm 1.09$ and $25 \pm 0.17 \mathrm{mg} / \mathrm{dl}$ 
respectively. The best serum VLDLc showed for group of rats fed on basal diet $+10 \%$ water-melon flesh, when compared to control $(+)$ and other treated groups.

Also, data of table (2) observed that the mean value of (AI) of control $(+)$ group was higher than control (-) group, being $4.69 \pm 0.05$ and $2.03 \pm 0.02$ respectively. The best AI showed for group 4 (rats fed on basal diet $+10 \%$ water-melon flesh) when compared to control $(+)$ group.

Lee et al., (2009) reported that ethanol extract of broccoli sprouts (BS) in rats fed high fat diet reduces LDL-cholesterol and atherogenic index.

Abu-Hiamed (2018) showed that incorporation of 10\% water-melon into the diet of the otherwise hypercholesterolemic rats led to significant reduction in serum levels of low-density lipoproteins which were in agreement with our results.

Table (2): Effect of two levels from water-melon flesh and broccoli sprouts in diet on $\mathrm{HDL}_{\mathfrak{c}}, \mathrm{LDL}_{\mathfrak{c}}, \mathrm{VLDL}_{\mathrm{C}}$ and $\mathrm{AI}$ of $\mathrm{KBrO3}$-intoxicated rats

\begin{tabular}{|c|c|c|c|c|}
\hline \begin{tabular}{|l} 
Parameters \\
Groups \\
\end{tabular} & $\begin{array}{c}\text { HDL }_{\mathbf{C}}(\mathrm{g} / \mathrm{dl}) \\
\text { Mean } \pm \text { SD }\end{array}$ & $\begin{array}{l}\operatorname{LDL}_{C}(\mathrm{~g} / \mathrm{dl}) \\
\operatorname{Mean} \pm \mathrm{SD}\end{array}$ & \begin{tabular}{|c|}
$\operatorname{VLDL}_{\mathrm{C}}(\mathrm{g} / \mathrm{dl})$ \\
Mean \pm SD
\end{tabular} & $\begin{array}{c}\text { AI } \\
\text { Mean } \pm \text { SD }\end{array}$ \\
\hline G1 (Control -ve) & $40.00^{\mathrm{c}} \pm 1.91$ & $56.00^{\mathbf{b}} \pm 0.98$ & $25.00^{\mathbf{b}} \pm 0.17$ & $2.03^{\mathbf{b}} \pm 0.02$ \\
\hline G2 (Control +ve) & $36.00^{\mathrm{d}} \pm 2.81$ & $134.00^{\mathrm{a}} \pm 3.01$ & $35.00^{\mathrm{a}} \pm 1.09$ & $4.69^{\mathrm{a}} \pm 0.05$ \\
\hline $\begin{array}{l}\text { G3 (Water-melon } \\
\text { flesh 5\%) }\end{array}$ & $45.00^{b} \pm 2.87$ & $32.00^{d} \pm 0.46$ & $23.00^{\mathbf{c}} \pm 0.40$ & $1.22^{\mathrm{d}} \pm 0.03$ \\
\hline $\begin{array}{l}\text { G4 (Water-melon } \\
\text { flesh } 10 \% \text { ) }\end{array}$ & $48.00^{\mathrm{a}} \pm 1.89$ & $28.00^{\mathrm{e}} \pm 0.82$ & $22.00^{\text {cd }} \pm 0.55$ & $1.04^{\mathrm{f}} \pm 0.02$ \\
\hline $\begin{array}{l}\text { G5 (Broccoli } \\
\text { sprouts 5\%) }\end{array}$ & $41.00^{\mathrm{c}} \pm 1.62$ & $46.00^{\mathbf{c}} \pm 0.39$ & $24.00^{\mathbf{b c}} \pm 0.31$ & $1.71^{\mathbf{c}} \pm 0.01$ \\
\hline $\begin{array}{l}\text { G6 (Broccoli } \\
\text { sprouts } 10 \%)\end{array}$ & 446.00 & 31.00 & $23.00^{\mathbf{c}} \pm 0.21$ & $1.17^{\mathrm{e}} \pm 0.01$ \\
\hline
\end{tabular}

- Least significant differences at $\mathrm{p} \leq 0.05$.

- Means with the same letter in each column are insignificantly difference.

Data presented in table (3) illustrate the effect of water-melon flesh and broccoli sprouts on total protein (TP), albumin (Alb.), Globulin (Glob.) and albumin/globulin (A/G) of KBrO3-intoxicated rats.

It could be observed that the mean value of (TP) of control $(+)$ group was lower than control (-) group, being $6.10 \pm 0.19$ and $8.40 \pm 0.09 \mathrm{~g} / \mathrm{dl}$ respectively. The best serum TP showed for group of rats fed on diet containing $10 \%$ water-melon flesh, when compared to control $(+)$ group.

It could be showed that the mean value of (Alb.) of control (+) group was lower than control (-) group, being $1.10 \pm 0.03$ and $4.70 \pm 0.02 \mathrm{~g} / \mathrm{dl}$ respectively. The best serum Alb was showed for group of rats fed on diet + 
$10 \%$ water-melon flesh followed by the group treated with $10 \%$ broccoli, respectively.

The same table indicated that the mean value of (Glob.) of control $(+)$ group was higher than control $(+)$ group, being $5.00 \pm 0.05$ and $3.70 \pm 0.03 \mathrm{~g} / \mathrm{dl}$ respectively. The best serum Glob. Showed for group of rats fed on diet containing 10\% broccoli sprouts, when compared to control (+) group.

Also, data of table (3) noticed that the mean value of (A/G) of control (-) group was higher than control $(+)$ group, being $1.27 \pm 0.005$ and $0.22 \pm 0.003$ respectively. The best $\mathrm{A} / \mathrm{G}$ showed for group of rats fed on diet containing $10 \%$ broccoli sprouts, when compared to control $(+)$ and other treated groups.

Cho et al., (2006) indicated that the antioxidative effect and protective potential against diabetes of the broccoli flower increases serum albumin.

El-Baz et al., (2012) investigated that broccoli extract increases total protein on carbon tetrachloride $(\mathrm{CCl} 4)$-induced liver injury in rats.

Altaş et al., (2011) indicated that watermelon juice increases albumin on carbon tetrachloride-induced toxicity in rats which agreed with our results.

Table (3): Effect of two levels from water-melon flesh and broccoli sprouts in diet on total protein (T.P), albumin (Alb.), globulin (Glob.) and albumin/globulin (A/G) of $\mathrm{KBrO3}$-intoxicated rats

\begin{tabular}{|c|c|c|c|c|}
\hline Groups & $\begin{array}{c}\text { T.P }(\mathrm{g} / \mathrm{dl}) \\
\text { Mean } \pm \text { SD }\end{array}$ & $\begin{array}{c}\text { Alb. (g/dl) } \\
\text { Mean } \pm \text { SD }\end{array}$ & $\begin{array}{l}\text { Glob. }(\mathrm{g} / \mathrm{dl}) \\
\text { Mean } \pm \text { SD }\end{array}$ & $\begin{array}{c}\text { A/G } \\
\text { Mean } \pm \text { SD }\end{array}$ \\
\hline G1 (Control -ve) & $8.40^{\mathrm{a}} \pm 0.09$ & $4.70^{\mathrm{a}} \pm 0.02$ & $3.70^{\mathrm{a}} \pm 0.03$ & $1.27^{\mathrm{e}} \pm 0.005$ \\
\hline G2 (Control +ve) & $6.10^{\mathrm{e}} \pm 0.19$ & $1.10^{\mathrm{d}} \pm 0.03$ & $5.00^{\mathrm{b}} \pm 0.05$ & $0.22^{\mathbf{f}} \pm 0.003$ \\
\hline $\begin{array}{l}\text { G3 (Water-melon } \\
\text { flesh } 5 \% \text { ) }\end{array}$ & $6.50^{\mathbf{c}} \pm 0.03$ & $4.40^{\mathbf{b}} \pm 0.02$ & $2.10^{\mathbf{c}} \pm 0.04$ & $2.10^{\mathbf{c}} \pm 0.002$ \\
\hline $\begin{array}{l}\text { G4 (Water-melon } \\
\text { flesh } 10 \% \text { ) }\end{array}$ & $6.70^{\mathbf{b}} \pm 0.02$ & $4.70^{\mathrm{a}} \pm 0.01$ & $2.00^{\mathbf{c}} \pm 0.03$ & $2.35^{\mathbf{b}} \pm 0.003$ \\
\hline $\begin{array}{l}\text { G5 (Broccoli } \\
\text { sprouts 5\%) }\end{array}$ & $6.30^{\mathrm{d}} \pm 0.05$ & $4.20^{\mathbf{c}} \pm 0.03$ & $2.10^{\mathbf{c}} \pm 0.02$ & $2.00^{\mathrm{d}} \pm 0.004$ \\
\hline $\begin{array}{l}\text { G6 (Broccoli } \\
\text { sprouts } 10 \%)\end{array}$ & $6.40^{\text {cd }} \pm 0.04$ & $4.50^{\mathbf{b}} \pm 0.01$ & $1.90^{\mathrm{d}} \pm 0.02$ & $2.37^{\mathrm{a}} \pm 0.002$ \\
\hline
\end{tabular}

- Least significant differences at $\mathrm{p} \leq 0.05$.

- Means with the same letter in each column are insignificantly difference.

Data presented in table (4) show the mean value of total bilirubin (TB), direct bilirubin (DB) \& indirect bilirubin (IB) of $\mathrm{KBrO} 3$-intoxicated rats treated with water-melon flesh and broccoli sprouts.

It could be noticed that the mean value of TB of control (-) group was lower than control $(+)$ group, being $0.20 \pm 0.001$ and $0.35 \pm 0.003 \mathrm{mg} / \mathrm{dl}$ respectively. Intoxicated rats fed on basal diet containing $10 \%$ broccoli sprouts 
showed the best treatment of $\mathrm{TB}$ followed by the group treated with $5 \%$ broccoli, respectively.

According data presented in the same table (4) it could be revealed that the mean value of DB of control (-) group was lower than control $(+)$ group, being $0.09 \pm 0.002$ and $0.12 \pm 0.003 \mathrm{mg} / \mathrm{dl}$ respectively. The best DB recorded for the group fed on (diet containing 5\% water-melon flesh), and also group fed on diet containing $5 \%$ broccoli, respectively.

The same table observed that the (IB) of control (-) group was lower than control $(+)$ group, being $0.11 \pm 0.002$ and $0.23 \pm 0.005 \mathrm{mg} / \mathrm{dl}$ respectively. Intoxicated rats fed on diet containing $10 \%$ water-melon flesh showed the best IB as compared to control (+) group.

Altaş et al., (2011) indicated that water-melon juice reduced total bilirubin of carbon tetrachloride-induced toxicity in rats.

EI-Baz et al., (2012) investigated that broccoli extract at the dose of 100 $\mathrm{mg} / \mathrm{kg}$ body weight was decreasing the activity of serum bilirubin, direct bilirubin and indirect bilirubin of carbon tetrachloride ( $\mathrm{CCl} 4)$-induced liver injury in rats.

Table (4): Effect of two levels from water-melon flesh and broccoli sprouts in diet on total bilirubin (T.B), direct (D.B) \& indirect (I.B) bilirubin of KBrO3-intoxicated rats

\begin{tabular}{|c|c|c|c|}
\hline Groups & $\begin{array}{l}\text { T.B }(\mathrm{mg} / \mathrm{dl}) \\
\text { Mean } \pm \mathrm{SD}\end{array}$ & $\begin{array}{l}\text { D.B }(\mathrm{mg} / \mathrm{dl}) \\
\text { Mean } \pm \text { SD }\end{array}$ & $\begin{array}{l}\text { I.B }((\mathrm{mg} / \mathrm{dl}) \\
\text { Mean } \pm \text { SD }\end{array}$ \\
\hline G1 (Control -ve) & $0.20^{\mathbf{e}} \pm 0.001$ & $0.09^{\mathrm{d}} \pm 0.002$ & $0.11^{\mathbf{c}} \pm 0.002$ \\
\hline G2 (Control +ve) & $0.35^{\mathbf{a}} \pm 0.003$ & $0.12^{\mathrm{a}} \pm 0.003$ & $0.23^{\mathrm{a}} \pm 0.005$ \\
\hline $\begin{array}{l}\text { G3 (Water-melon } \\
\text { flesh 5\%) }\end{array}$ & $0.30^{\mathbf{b}} \pm 0.004$ & $0.09^{d} \pm 0.001$ & $0.21^{\mathbf{b}} \pm 0.003$ \\
\hline $\begin{array}{l}\text { G4 (Water-melon } \\
\text { flesh } 10 \% \text { ) }\end{array}$ & $0.26^{\mathbf{c}} \pm 0.005$ & $0.11^{\mathbf{b}} \pm 0.002$ & $0.09^{\mathrm{e}} \pm 0.002$ \\
\hline $\begin{array}{l}\text { G5 (Broccoli } \\
\text { sprouts 5\%) }\end{array}$ & $0.21^{\mathbf{d}} \pm 0.002$ & $0.11^{\mathbf{b}} \pm 0.004$ & $0.10^{\mathrm{d}} \pm 0.005$ \\
\hline $\begin{array}{l}\text { G6 (Broccoli } \\
\text { sprouts } 10 \% \text { ) }\end{array}$ & $0.20^{\mathbf{e}} \pm 0.006$ & $0.10^{\mathbf{c}} \pm 0.003$ & $0.10^{d} \pm 0.003$ \\
\hline
\end{tabular}

- Least significant differences at $\mathrm{p} \leq 0.05$.

- Means with the same letter in each column are insignificantly difference.

Data of table (5) indicate the effect of water-melon flesh and broccoli sprouts on serum levels of AST, ALT, ALP enzymes \& (AST/ALT) ratio of $\mathrm{KBrO} 3$-intoxicated rats.

It could be observed that the mean value of AST enzyme activity of control (+) group was higher than control (-) group, being $195 \pm 3.98$ and $33 \pm 1.13$ (U/L) respectively. The best treatment observed for group of rats fed on diet containing $10 \%$ water-melon flesh, when compared to control $(+)$ group.

It could be noticed that the mean value of ALT enzyme activity of 
control (+) group was higher than control (-) group, being 58 \pm 0.59 and $18 \pm 0.12$ $(\mathrm{U} / \mathrm{L})$ respectively. The best treatment observed for group of rats fed on diet containing 10\% water-melon flesh, when compared to control (+) group.

Data of the same table (5) illustrate the mean value of ALP enzyme activity of control (+) group was higher than control (-) group, being $301 \pm 5.02$ and $59 \pm 1.88(\mathrm{U} / \mathrm{L})$ respectively. Group of rats which treated with (broccoli sprouts $10 \%$ ) showed the lowest mean value of ALP enzyme level as compared to control $(+)$ group and other treated groups.

It could be noticed that the mean value of (AST/ALT) of control $(+)$ group was higher than control (-) group, being $3.36 \pm 0.03$ and $1.83 \pm 0.01$ respectively. The best treatment observed for group 4 (water-melon flesh $10 \%$ ) when compared to control $(+)$ group.

Morsy et al., (2010) reported that oral administration of broccoli extracts caused significant reduction in serum levels of AST, ALT and ALP against hepatocellur carcinoma induced by $\mathrm{N}$ - Nitrosodiethyamine (NDEA) in male rats.

Hong et al., (2015) indicated that aspartate aminotransferase, alanine aminotransferase and alkaline phosphatase were significantly lower in dextran sodium sulfate (DSS)-treated rats fed on atherogenic diet when watermelon was consumed.

Table (5): Effect of two levels from water-melon flesh and broccoli sprouts in diet on AST, ALT, AST/ALT and ALP of KBrO3-intoxicated rats

\begin{tabular}{|c|c|c|c|c|}
\hline Groups & $\begin{array}{l}\text { AST (U/L) } \\
\text { Mean } \pm \text { SD }\end{array}$ & $\begin{array}{l}\text { ALT (U/L) } \\
\text { Mean } \pm \text { SD }\end{array}$ & $\begin{array}{c}\text { AST/ALT } \\
\text { Mean } \pm \text { SD } \\
\end{array}$ & $\begin{array}{l}\operatorname{ALP}(\mathrm{U} / \mathrm{L}) \\
\operatorname{Mean} \pm \mathrm{SD}\end{array}$ \\
\hline G1 (Control-ve) & $33.00^{\mathrm{cd}} \pm 1.13$ & $18.00^{\text {cd }} \pm 0.12$ & $1.83^{\mathbf{b}} \pm 0.01$ & $59.00^{\mathrm{f}} \pm 1.88$ \\
\hline e) & \pm 3.98 & 0.59 & $3.36^{\mathrm{a}} \pm 0.03$ & $301.00^{\mathrm{a}} \pm 5.0$ \\
\hline nelon & 32 . & .26 & 2 & .98 \\
\hline $\begin{array}{l}\text { iter-melon } \\
\%)\end{array}$ & 29. & 0.71 & $\overline{\mathrm{e}} \pm 0.05$ & $\bar{d}$ \\
\hline $\begin{array}{l}\text { G5 (Broccoli } \\
\text { sprouts 5\%) }\end{array}$ & 36.0 & \pm 0.28 & $1.71^{\mathbf{c}} \pm 0.02$ & $\overline{\mathbf{b}^{\mathbf{b}} \pm 3.2}$ \\
\hline & 34. & 34 & .03 & \\
\hline
\end{tabular}

- Least significant differences at $\mathrm{p} \leq 0.05$.

- Means with the same letter in each column are insignificantly difference. 
Data presented in table (6) indicated the effect of water-melon flesh and broccoli sprouts on serum glucose of $\mathrm{KBrO} 3$-intoxicated rats. It could be observed that the mean value of glucose of control $(+)$ group was higher than control (-) group, being $220 \pm 6.01$ and $95 \pm 2.98(\mathrm{mg} / \mathrm{dl})$ respectively. The best serum glucose observed for group of rats fed on diet containing $10 \%$ watermelon flesh) followed by the groups which were treated with the two levels of broccoli, respectively.

Oseni et al., (2015) reported the benefits of water-melon juice as they significantly reduced the extent of antioxidant loss and restored level of diabetes caused by alloxan in the rat. All the biochemical analysis showed water-melon effectively protected pancreatic cells death. They suggested that water-melon has a beneficial effect on diabetes. The hypoglycemic potential shown by water-melon might be due to the presence of some bioactive compounds in the plant juice.

Suresh et al., (2017) found that broccoli extract (BE) reduced the STZ mediated hyperglycaemia and the STZ-induced oxidative injury to pancreas tissue in rats.

Table (6): Effect of two levels from water-melon flesh and broccoli sprouts in diet on fasting serum glucose of $\mathrm{KBrO3}$-intoxicated rats

\begin{tabular}{|c|c|}
\hline $\begin{array}{ll}\text { Groups } & \text { Parameters } \\
\end{array}$ & $\begin{array}{c}\text { Glucose }(\mathrm{mg} / \mathrm{dl}) \\
\text { Mean } \pm \text { SD }\end{array}$ \\
\hline G1 (Control -ve) & $95.00^{\mathrm{e}} \pm 2.98$ \\
\hline G2 (Control +ve) & $220.00^{\mathrm{a}} \pm 6.01$ \\
\hline G3 (Water-melon flesh 5\%) & $110.00^{\mathbf{b}} \pm 3.28$ \\
\hline G4 (Water-melon flesh 10\%) & $98.00^{d} \pm 2.66$ \\
\hline G5 (Broccoli sprouts 5\%) & $105.00^{\mathbf{c}} \pm 4.03$ \\
\hline G6 (Broccoli sprouts 10\%) & $106.00^{\mathbf{c}} \pm 2.85$ \\
\hline
\end{tabular}

- Least significant differences at $\mathrm{p} \leq 0.05$.

- Means with the same letter in each column are insignificantly difference.

Results of table (7) illustrated the mean value of serum creatinine, urea and uric acid (mg/dl) on KBrO3-intoxicated rats fed on various diets.

It could be observed that the mean value of creatinine of control $(+)$ group was higher than control (-) group, being $3 \pm 0.05$ and $0.62 \pm 0.03 \mathrm{mg} / \mathrm{dl}$ respectively. Group of rats fed on diet containing $10 \%$ broccoli sprouts, recorded the best result, followed by the groups treated with $5 \%$ water-melon 
flesh.

The same table (7) show that mean value of urea of control $(+)$ group was higher than control (-) group, being $93 \pm 3.87$ and $20 \pm 2.05 \mathrm{mg} / \mathrm{dl}$ respectively. In concern to urea the best treatment recorded for the group fed on diet containing $10 \%$ water-melon flesh, when compared to control $(+)$ group.

It could be noticed that the mean value of uric acid of control ( + ) group was higher than control (-) group, being $5.80 \pm 0.05$ and $2.10 \pm 0.02 \mathrm{mg} / \mathrm{dl}$ respectively. Group of rats fed on diet containing $10 \%$ water-melon flesh, recorded the best result as compared to other groups.

Francis et al., (2017) found that fruit juice of watermelon reduced urea and creatinine levels of cadmium induced toxicity on male albino rats.

Saxena and Shahani (2017) indicated that broccoli sprouts powder significantly reduced elevated level of serum urea and creatinine against continuous ingestion of antidepressant drug induced nephrotoxicity in Swiss albino mice.

Table (7): Effect of two levels from water-melon flesh and broccoli sprouts in diet on creatinine (Creat), urea, and uric acid (U Acid) of KBrO3-intoxicated rats

\begin{tabular}{|l|c|c|c||}
\hline $\begin{array}{l}\text { Groups } \\
\text { Parameters }\end{array}$ & $\begin{array}{c}\text { Creatinine (mg/d) } \\
\text { Mean } \pm \text { SD }\end{array}$ & $\begin{array}{c}\text { Urea (mg/d) } \\
\text { Mean } \pm \text { SD }\end{array}$ & $\begin{array}{c}\text { Uric acid (mg/dl) } \\
\text { Mean } \pm \text { SD }\end{array}$ \\
\hline G1 (Control -ve) & $0.62^{\mathbf{e}} \pm 0.03$ & $20.00^{\mathbf{d}} \pm 2.05$ & $2.10^{\mathbf{e}} \pm 0.02$ \\
\hline \hline G2 (Control +ve) & $3.00^{\mathbf{a}} \pm 0.05$ & $93.00^{\mathbf{a}} \pm 3.87$ & $5.80^{\mathbf{a}} \pm 0.05$ \\
\hline $\begin{array}{l}\text { G3 (Water-melon } \\
\text { flesh 5\%) }\end{array}$ & $2.70^{\mathbf{b}} \pm 0.02$ & $47.00^{\mathbf{c}} \pm 1.16$ & $5.40^{\mathbf{c}} \pm 0.04$ \\
\hline $\begin{array}{l}\text { G4 (Water-melon } \\
\text { flesh 10\%) }\end{array}$ & $2.50^{\mathbf{c}} \pm 0.05$ & $46.00^{\mathbf{c}} \pm 2.25$ & $5.20^{\mathbf{d}} \pm 0.03$ \\
\hline $\begin{array}{l}\text { G5 (Broccoli } \\
\text { sprouts 5\%) }\end{array}$ & $2.60^{\mathbf{b c}} \pm 0.04$ & $49.00^{\mathbf{b}} \pm 1.61$ & $5.50^{\mathbf{b}} \pm 0.02$ \\
\hline $\begin{array}{l}\text { G6 (Broccoli } \\
\text { sprouts 10\%) }\end{array}$ & $2.40^{\mathbf{c d}} \pm 0.03$ & $50.00^{\mathbf{b}} \pm 2.03$ & $5.40^{\mathbf{c}} \pm 0.04$ \\
\hline
\end{tabular}

- Least significant differences at $\mathrm{p} \leq 0.05$.

- Means with the same letter in each column are insignificantly difference.

Data of table (8) revealed pronounced decreases in activity of (CAT, GPX and SOD) due to injection with $\mathrm{KBrO} 3$ induced marked oxidation stress.

Nevertheless feeding on water-melon flesh and broccoli sprouts diets raised the antioxidant activities. Best sample treatment recorded for group of rats fed on diet containing $10 \%$ water-melon flesh. 
Oseni et al., (2015) indicated that water-melon juice increased GPx, catalase, and SOD in alloxan-induced diabetic male Wistar albino rats.

Oyenihi et al., (2016) showed that Oral administration of water-melon juice for fifteen (15) days prior to ethanol intoxication increased catalase and GPX induced oxidative stress in the liver and brain of male Wistar rats. They reported that watermelon juice demonstrate anti-oxidative effects in ethanolinduced oxidation in the liver and brain of rats; which could be associated with the plethora of antioxidant phyto-constituents present there like phenol and alkaloids.

Morsy et al., (2010) revealed that oral administration of broccoli extracts increased in GPX, SOD and CAT induced by N- Nitrosodiethyamine (NDEA) in male rats.

Sharma and Sangha (2016) reported that glucosinolates rich broccoli (Br) extract increased catalase (CAT), superoxide dismutase (SOD) and glutathione peroxidase (GPx) induced toxicity in Wistar rats.

Table (8): Effect of two levels from water-melon flesh and broccoli sprouts in diet on serum antioxidant enzymes (CAT, GPX and SOD) of $\mathrm{KBrO3}$-intoxicated rats

\begin{tabular}{|l|c|c|c||}
\hline \multicolumn{1}{|c|}{ Parameters } & $\begin{array}{c}\text { CAT } \\
(\mathbf{m m o l} / \mathbf{L}) \\
\text { Mean } \pm \text { SD }\end{array}$ & $\begin{array}{c}\text { GPX } \\
(\mathbf{n g} / \mathbf{m l}) \\
\text { Gean } \pm \text { SD }\end{array}$ & $\begin{array}{c}\text { SOD } \\
\text { (U/L) } \\
\text { Mean } \pm \text { SD }\end{array}$ \\
\hline G1 (Control -ve) & $38.16^{\mathbf{a}} \pm 0.95$ & $66.80^{\mathbf{a}} \pm 0.96$ & $57.34^{\mathrm{a}} \pm 0.68$ \\
\hline \hline G2 (Control +ve) & $15.28^{\mathbf{d}} \pm 0.83$ & $21.04^{\mathbf{e}} \pm 0.62$ & $19.25^{\mathrm{b}} \pm 0.15$ \\
\hline \hline $\begin{array}{l}\text { G3 (Water-melon } \\
\text { flesh 5\%) }\end{array}$ & $36.14^{\mathbf{b}} \pm 0.01$ & $63.25^{\mathbf{c}} \pm 0.44$ & $54.61^{\mathrm{c}} \pm 0.21$ \\
\hline $\begin{array}{l}\text { G4 (Water-melon } \\
\text { flesh 10\%) }\end{array}$ & $38.00^{\mathbf{a}} \pm 1.00$ & $65.17^{\mathbf{b}} \pm 0.31$ & $56.08^{\mathrm{b}} \pm 0.23$ \\
\hline $\begin{array}{l}\text { G5 (Broccoli } \\
\text { sprouts 5\%) }\end{array}$ & $32.26^{\mathbf{c}} \pm 0.75$ & $56.40^{\mathbf{d}} \pm 0.11$ & $40.53^{\mathrm{e}} \pm 0.30$ \\
\hline $\begin{array}{l}\text { G6 (Broccoli } \\
\text { sprouts 10\%) }\end{array}$ & $33.19^{\mathbf{c}} \pm 0.25$ & $58.71^{\mathbf{c}} \pm 0.35$ & $43.61^{\mathrm{d}} \pm 0.53$ \\
\hline
\end{tabular}

- Least significant differences at $\mathrm{p} \leq 0.05$.

- Means with the same letter in each column are insignificantly difference. 
References:

Abu-Hiamed, H. (2018): Hypocholesterolemic effects of water-melon fruit rind on rats. Nutrition \& Food Science, 48(5), 836-845.

Ahmed, M.K. \& Mahmood, R. (2012): Oral administration of potassium bromate, a major water disinfection byproduct, induces oxidative stress and impairs the antioxidant power of rat blood. Chemosphere, 87(7):750-756.

Allen, C.C. (1974): Cholesterol enzymatic colorimetric method. J. Clin. Chem., (20): 470.

Altaş, S.; Kızıl, G.; Kızıl, M.; Ketani, A. and Haris, P.I. (2011): Protective effect of Diyarbakır water-melon juice on carbon tetrachlorideinduced toxicity in rats. Food and Chemical Toxicology, 49(9), $2433-2438$.

Belfield, A. and Goldberg, D.M. (1971): Alkaline phosphatase colorimetric method. J. of Enzyme, (12):561.

Charry, T.M. and Sharma, H. (2004): Bacterial Biochemistry for Medical and Dental Student. Jaype Brothers Medical Puplisher (p) LTD, New Delhi.

Cho, E. J.; Lee, Y.A.; Yoo, H. H. and Yokozawa, T. (2006): Protective effects of broccoli (Brassica oleracea) against oxidative damage in vitro and in vivo. Journal of nutritional science and Vitaminology, 52(6), 437-444.

Doumas, B.T.; Ferry, B.W.; Sasse, E.A. and Straum, J.V. (1971): Clinica. Aplicada. Amposta. Spain. Clin. Chem., 19: 984-993.

Doumas, B.T.; Kwok-Cheung, P.P.; Perry, B.W.; Jendrzejczak, B.; McComb, R.B.; Schaffer, R. and Hause, L.L. (1985): Candidate reference method for determination of total bilirubin in serum: development and validation. Clinical chemistry, 31(11), 1779-1789.

El-Baz, F.K.; Salama, Z.A. and Gaafar, A.A. (2012): Evaluation of Hepatoprotective effect of broccoli extract against $\mathrm{Ccl}^{\wedge} \mathrm{Sub} 4^{\wedge}$ in rats. International Journal of Medical and Biological Frontiers, 18(7), 521.

Fossati, P. and Prencipe, L. (1982): Triglyceride enzymatic colorimetric method. J. Clin. Chem., (28): 2077.

Fossatti, P. and Prencipe, L. (1980): Enzymatic colorimetric test of uric acid. J. Clin. Chem., 28:227.

Francis, A.; Beauty, N.; Kelechi, N. and Comfort, M. I. (2017): Effect of combined fruit juice of Citrullus lanatus and Cucumis sativus on cadmium induced hepatotoxicity and nephrotoxicity in male Wister rats. Acad. J. Biosci., 2017; 5(10):732-743. 
Gomal, N.J.; Azuma, K. and Van Denmark, P.J. (1949): Determination of total protein. Arch. Biocheme. Biology., 88: 250-255.

Gwana, A. M.; Bako, M. M.; Bagudu, B. Y.; Sadiq, A. B. and Abdullahi, M. M. (2014): Determinations of phytochemical, vitamin, mineral and proximate compositions of varieties of water-melon seeds cultivated in Borno State, North-Eastern Nigeria. International Journal of Nutrition and Food Sciences, 3(4): 238245.

Henry, R.J. (1974): Clinical Chemistry Principles and Techniques. 2nd Ed., Harper and Publishers, NewYork. Philadelphia.

Hong, M.Y.; Hartig, N.; Kaufman, K.; Hooshmand, S.; Figueroa, A. and Kern, M. (2015): Water-melon consumption improves inflammation and antioxidant capacity in rats fed an atherogenic diet. Nutrition Research, 35(3), 251-258.

Kaplan, L.A. (1984): Clinical Chemistry. The C.V. Mosby Co. St Louis. Toronto. Princeton, 1032-1036.

Khan, N. \& Sultana, S. (2004): Abrogation of potassium bromate induced renal oxidative stress and tumor promotion response by soy isoflavones in Wistar rats. Toxicology 201(1-3):173-84.

Khan, R.A.; Khan, M.R. \& Sahreen, S. (2013): Protective effects of SonchuSasper (L.) against $\mathrm{KBrO}_{3}$-induced oxidative stress in rat testis. Pak J Pharm Sci., 26: 567-570.

Kikuchi, H.; Onodera, N.; Matsubara, S., Yassudo, E.; Chonan,O.; Takahashi, R. and Ishikawa, F. (1998): Effect of soy milk on lipid metabolism in aged ovariectomized rats. Bioscience, Biotechnology and Biochemistry, 62(9): 1688 - 1692.

Lee, J. J.; Shin, H.D.; Lee, Y. M.; Kim, A. R. and Lee, M. Y. (2009): Effect of broccoli sprouts on cholesterol-lowering and anti-obesity effects in rats fed high fat diet. Journal of the Korean Society of Food Science and Nutrition, 38(3), 309-318.

Lee, R. and Nieman, D. (1996): Nutritional Assessment.2nd Ed., Mosby, Missouri,USA.

Lopez, M.F. (1997): HDL- Cholesterol colorimetric method. J. Clin. Chem., (23): 282-289.

M de Figueiredo, S.; S Binda, N.; A Nogueira-Machado, J.; A Vieira-Filho, S. and B Caligiorne, R. (2015): The antioxidant properties of organosulfur compounds (sulforaphane). Recent Patents on Endocrine, Metabolic \& Immune Drug Discovery, 9(1): 24-39.

Mahn, A. and Reyes, A. (2012): An overview of health-promoting compounds of broccoli (Brassica oleracea var. italica) and the effect of processing. Food Science and Technology International, 18(6): 503-514. 
Makaepea, m. m.; Daniso, B. and Afam, O. J. (2019): Watermelon as a potential fruit snack. International Journal of Food Properties, 22 (1), https://doi.org/10.1080/10942912.2019.1584212.

Malhotra, V. K. (2003): Practical Biochemistry for Students. Fourth Edition, Jaypee Brothers Medical Publishers (p) LTD, New Delhi.

Moreno, D. A.; Carvajal, M.; López-Berenguer, C. and García-Viguera, C. (2006): Chemical and biological characterisation of nutraceutical compounds of broccoli. Journal of Pharmaceutical and Biomedical Analysis, 41(5):1508-1522.

Morsy, A.F.; Ibrahima, H.S. and Shalabyb, M.A. (2010): Protective effect of broccoli and red cabbage against hepatocellular carcinoma induced by $\mathrm{N}$-nitrosodiethylamine in rats. J. Am. Sci., 6: 113644.

Naif, G. A.; Jamaan, A.; Ahmed, A. A.; Saleh, N. M. and Mostafa, A. A. (2018): Deleterious effects of potassium bromate administration on renal and hepatic tissues of Swiss mice. Saudi J. Biol. Sci, 25(2): 278-284.

Oseni, O.A.; Odesanmi, O.E. and Oladele, F.C. (2015): Antioxidative and antidiabetic activities of water-melon (Citrullus lanatus) juice on oxidative stress in alloxan-induced diabetic male Wistar albino rats. Nigerian Medical Journal (journal of the Nigeria Medical Association) 56(4), 272.

Oyenihi, O.R.; Afolabi, B.A.; Oyenihi, A.B.; Ogunmokun, O.J. and Oguntibeju, O.O. (2016): Hepato-and neuro-protective effects of water-melon juice on acute ethanol-induced oxidative stress in rats. Toxicology reports, 3, 288-294.

Patton, C.J. and Crouch, S.R. (1977): Enzymatic determination of urea. J. Anal. Chem., 49: 464- 469.

Perkins-Veazie, P.; Collins, J.K. and Chevidence, B. (2007): Water-melons and health. Acta Hortic., 731: 121-128.

Pizzino, G.; Irrera, N.; Cucinotta, M.; Pallio, G.; Mannino, F., Arcoraci, V. \& Bitto, A. (2017): Oxidative stress: Harms and benefits for human health. Oxidative Medicine and Cellular Longevity, IT.

Ravikumar, C. (2015): Therapeutic potential of Brassica oleracea (broccoli)A review. Int J Drug Dev \& Res., 7(2): 009-010.

Romdhane, M. B.; Haddar, A., Ghazala, I.; Jeddou, K. B.; Helbert, C. B. and Ellouz-Chaabouni, S. (2017): Optimization of polysaccharides extraction from watermelon rinds: Structure, functional and biological activities. Food Chemistry, 216: 355364. 
SAS (1988): SAS/STAT User's Guide, Release 6.03. Cary, North Carolina: SAS Institute.

Saxena, S. and Shahani, L (2017): Ameliorative effect of broccoli powder on renal toxicity in mice caused by continuous exposure to Escitalopram Antidepressant Drug. Int. Res. J. Pharm., 8 (11).

Sepulveda, B. and Osterberg, A. E. (1943): Serum bilirubin: A procedure for the determination of indirect and direct values. The Journal of Laboratory and Clinical Medicine, 28(11):1359-1368.

Sharma, D. and Sangha, G.K. (2016): Effects of glucosinolates rich broccoli extract against triazophos induced toxicity in Wistar rats. A Randomized Control Study. J Biomedical Sci, 5, 4.

Suresh, S.; Waly, M. I.; Rahman, M. S.; Guizani, N.; Al-Kindi, M. A. B.; Al-Issaei, H.K.A. and Al-Salami, A. (2017): Broccoli (Brassica oleracea) reduces oxidative damage to pancreatic tissue and combats hyperglycaemia in diabetic rats. Preventive Nutrition and Food Science, 22(4): 277.

Thanh, N. L.; Hong, Q. L.; Hsin-Ping, L.; Chiu-Hsia, C. and Pao-Chuan, H. (2019): Broccoli (Brassica oleracea L. var. italica) Sprouts as the Potential Food Source for Bioactive Properties: A Comprehensive Study on In Vitro Disease Models. J. Foods, 8(11): 532

Tietz, N.W. (1976): Fundamentals of Clinical Chemistry. Philadelphia. B. W. Saunders, P. 243.

Vale, A. P.; Santos, J.; Brito, N. V.; Fernandes, D.; Rosa, E. and Oliveira,

M. B. P. (2015): Evaluating the impact of sprouting conditions on the glucosinolate content of Brassica oleracea sprouts. Phytochemistry, 115: 252-260.

Yound, D.S. (1975): Determination of GOT. J. Clin. Chem., 21: 1- 6. 


\section{Abstract \\ Water-melon Flesh and Broccoli Sprouts as Used to Cope the Oxidation Induced by Potassium Bromate.}

The present study was designed to investigate potential protective and ameliorate effects of red water-melon flesh (meat) and broccoli sprouts powders against potassium bromate $\left(\mathrm{KBrO}_{3}\right)$-induced oxidative stress using experimental rats. Thirty-six (36) adult male albino rats were randomly distributed into 6 equal groups, 6 rats of each. Group 1 was fed on the basal diet and set as a negative control group (normal rats). The other 5 groups were injected by a single intraperitoneal dose of potassium bromate at dose of 125 $\mathrm{mg} / \mathrm{kg}$ body weight for induction of oxidative stress. Group 2 was left as a positive control group and fed on basal diet only, while others groups 3, 4, 5, and 6 were fed on supplemented diet with $5 \%$ powder of water-melon flesh, $10 \%$ water-melon flesh, $5 \%$ broccoli sprouts and $10 \%$ broccoli sprouts respectively. Feeding on melon flesh and broccoli sprouts (G3, G4, G5 \& G6) caused significant $(\mathrm{P} \leq 0.05)$ increase in HDL, total protein and albumin, but with significant $(\mathrm{P} \leq 0.05)$ decreases of globulin, LDL,VLDL, TC, TG, ALT, AST, ALP, creatinine, uric acid, urea and glucose as well as the activities of CAT,GPX \&SOD which reflects the powerful nutraceutical therapeutic effect for feeding on water-melon flesh and broccoli sprouts to combat the oxidation stress induced by $\mathrm{KBrO}_{3}$ in male albino rats. Best treatments were for watermelon flesh $10 \% \&$ broccoli sprouts $10 \%$ followed by water-melon flesh $5 \%$ then broccoli sprouts $5 \%$.

Key words: Potassium bromate $\left(\mathrm{KBrO}_{3}\right)$ - Oxidation - Melon flesh - Broccoli sprouts. 


\section{ملخص البحث}

\section{استخدام لحم البطيخ ويراعم البروكلى لمقاومة التأكسد المحدث بواسطة برومات البوتاسيوم}

تم إجراء الدراسـة الحالية لمعرفة التأثثرات التغذويـة العلاجية المحتملة لمساحيق لحم البطيخ

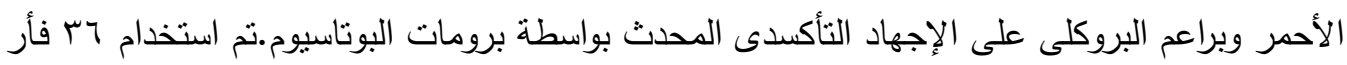

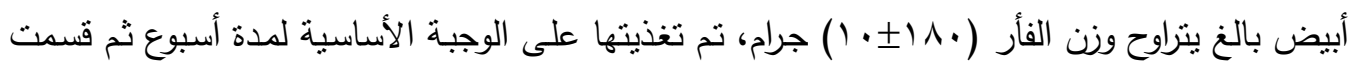
بعد ذلك إلى 1 مجموعات منساوية وتركت إحداها كمجموعـة ضـابطة سالبة، أمسا المجموعات الثمانية

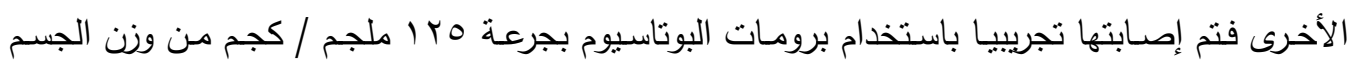

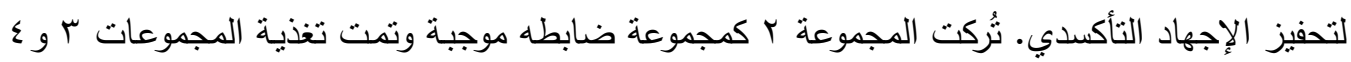

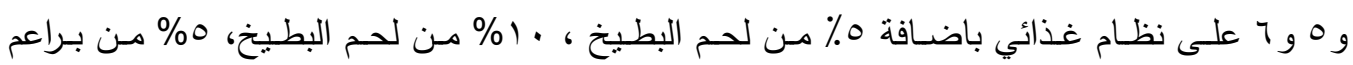

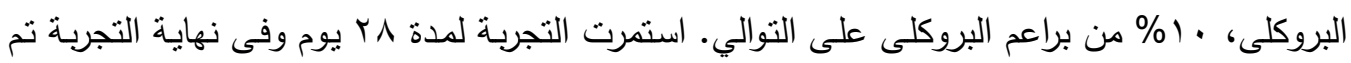

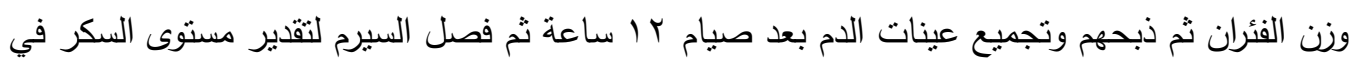

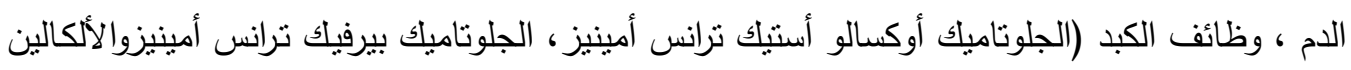

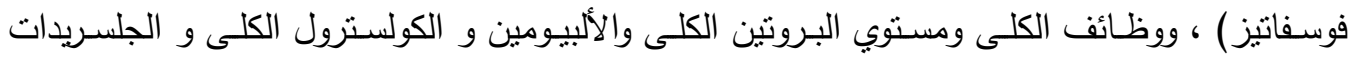

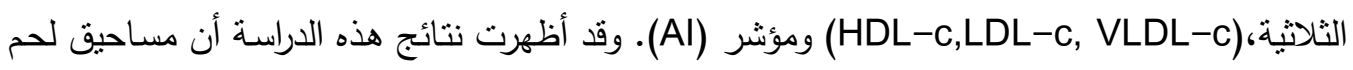

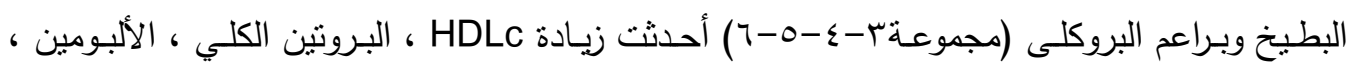

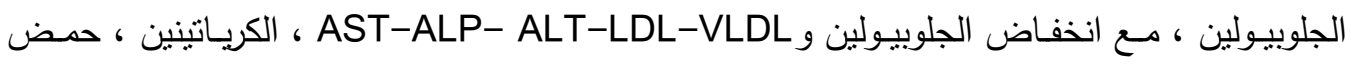

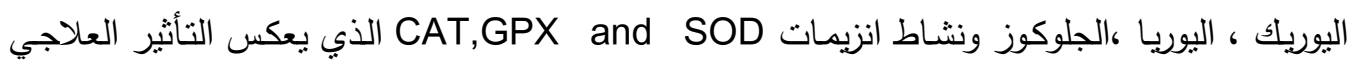

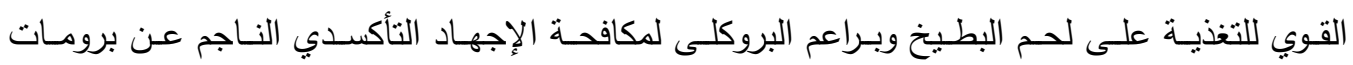

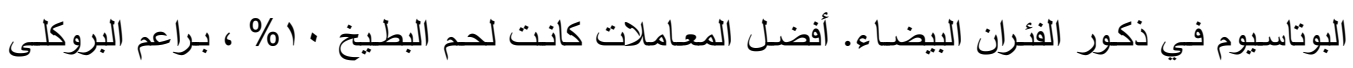

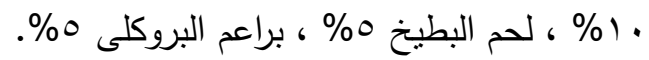

الكلمات المفتاحية: برومات البوتاسيوم- التأكسد - لحم البطيخ - براعم البروكلى . 